\title{
Family Communication Portrait in the Middle of Social Change in Bogor
}

\author{
Firdanianty Pramono ${ }^{1}$, Djuara P. Lubis ${ }^{2}$, Herien Puspitawati ${ }^{3}$, \\ Djoko Susanto ${ }^{4}$
}

\author{
${ }^{1}$ Communication Studies, \\ Candradimuka College of Social and Political Sciences, Palembang, Indonesia \\ Jl. Swadaya Sekip Ujung, Palembang, South Sumatera. Telp. (0711) 811542 \\ ${ }^{2,4}$ Communication of Development Studies; ${ }^{3}$ Family and Consumer Studies, \\ Faculty of Human Ecology, Bogor Agricultural University, Bogor, Indonesia \\ Jl. Raya Dramaga, Bogor 16680, West Java, Indonesia. \\ Email: firda_nianty@stisipolcandradimuka.ac.id, firdanianty.pramono@gmail.com
}

\begin{abstract}
The advancement of information and communication technology have a positive and negative impacts on family ties and values. These developments also change the order of family life as the smallest unit in society. Family interaction and communication also change along with social change in society. The purposes of this study are: first, to explore the topics of conversation and interaction of adolescents with their families. Second, to depict four types of communication between adolescents and their families. This study was conducted for six (6) months in six (6) high schools in Bogor City with qualitative methods. Data were obtained through focus group discussion (FGD) in each high school with a total of 12 FGDs. The number of informants involved in the FGD were 60 students aged 15-18 years old. The FGD results show that most of theadolescents shared their personal problems to peers than to parents. The topics presented by adolescents to parents included events at school (lessons, teachers, friends), television shows, ideals, sports, and politics. Some adolescents who had close relationships with parents did not hesitate to share their personal problems and interests of the opposite sex to their parents. Adolescents who had closeness to parents tend to be more open and were able to control their emotions. The findings of this study are expected to provide inputto the family as well as to improve the quality of communication between adolescents and parents.
\end{abstract}

Keywords: Family Communication, Adolescents, Social Change, Bogor

\begin{abstract}
Abstrak
Kemajuan teknologi informasi dan komunikasi memberi dampak positif maupun negatif terhadap ikatan dan nilai-nilai keluarga. Perkembangan tersebut juga mengubah tatanan kehidupan keluarga sebagai unit terkecil di masyarakat. Interaksi dan komunikasi keluarga berubah seiring perubahan sosial di masyarakat. Tujuan penelitian ini adalah: pertama, mengeksplorasi topik pembicaraan dan interaksi remaja dengan keluarga. Kedua, memetakan empat tipologi komunikasi remaja dengan keluarga. Penelitian dilakukan selama enam (6) di enam SMA di Kota Bogor dengan metode kualitatif. Data diperoleh melalui focus group discussion (FGD) di masing-masing SMA dengan total FGD sebanyak 12 kali. Jumlah informan yang terlibat dalam FGD sebanyak 60 siswa berusia 15-18 tahun. Hasil FGD menunjukkan bahwa remaja lebih sering menceritakan masalah pribadinya kepada teman sebaya dibandingkan orang tua. Topik-topik yang disampaikan remaja kepada orang tua antara lain kejadian di sekolah (pelajaran, guru, teman-teman), acara televisi, cita-cita, olahraga, dan politik. Beberapa remaja yang memiliki hubungan dekat dengan orang tua tidak segan menceritakan masalah pribadi dan ketertarikan dengan lawan jenis. Remaja yang memiliki kedekatan dengan orang tua cenderung bersikap terbuka dan mampu mengendalikan emosinya. Temuan penelitian ini diharapkan menjadi masukan bagi keluarga sekaligus dapat meningkatkan kualitas komunikasi remaja dengan orang tua.
\end{abstract}

Kata kunci: Komunikasi Keluarga, Remaja, Perubahan Sosial, Bogor 


\section{Introduction}

The rapid development of science and technology has accelerated social change in society. Friedman (2009) mentions the era that is dominated by the power of communication and information technology with the term the world is flat. On the one hand, the ease of technology allows everyone to interact with others so easily because the world has become flat. There are no more barriers that restrict people from communicating and cooperating with anyone. The technological revolution also forces everyone to accept changes. For example, correspondence, congratulations, and invitations, are now sent via short messages, e-mail, or social networks like Facebook and Instagram. Responding to these conditions, the community is required to follow the changes that are taking place at this time.

On the other hand, the use of communication and information technology - including the use of devices, in particular gadgets excessively - can interfere the interaction and communication process. Children, especially adolescents, spend more time in front of the device or computer, thus affecting their social and emotional development (Barus, 2013). Carr (2011) revealed that the duration a person needs to access online media is increasing every year. The results of research on American children aged 2-11 years old show that in 2009 they have used the internet around 11 hours a week or increased by more than 60 percent since 2004. However, the data did not include the time a person spends on a cell phone and laptop. An American adolescent, in average, could send or receive 2,272 texts every month. Around the world, more than two trillion instant messages pass between cell phones every year. The research of Anderson \& Jiang (2018) explained that YouTube, Instagram, and Snapchat are the most popular online platforms among US adolescents. Fully $95 \%$ of adolescents have access to a smartphone, and $45 \%$ say they are online almost constantly.

Technological developments can further strengthen or even create communication gaps between parents and children. At first, the device functions to facilitate farreaching interpersonal communication (Barus, 2013). Unfortunately, device users now spend more time with their devices than sharing or talking with family members. The opportunity for adolescents to skate in cyberspace is recognized by Tapscott (2013) giving them the opportunity to get know the world more broadly.

However, the uncontrolled use of devices actually disrupts communication and social interaction within the family (Oprea \& Stan, 2012, Morentin, et al., 2014, Ballarotto, et al., 2018). Suarmini (2014) pointed that the family environment is the first and foremost media directly or indirectly influences children's behavior. If there is a deviation in the process of individual formation, it is a series of results from the influence of the family and the environment outside it (Goldberg \& Carlson, 2014). Therefore, in order to the child's growth and development process take place optimally, parents must fulfill the 
child's basic needs which include the need for attention and affection. Especially when entering adolescence, children experience transition period characterized by personal changes in all aspects of physical, social and psychological as well. At these times, the needs of adolescents to express themselves and socialize with their peers develop. Adolescents feel that they are already independent, have a great curiosity, always want to try many new things that they have not known before, and do not want to miss their friends (Steinberg, 2014).

Adolescents also face competition for influence between families and their peers. This peer group is very different in position from family and school (Brown \& Larson, 2009). Peers can also have a positive influence on adolescents, on the other hand they can also have negative effects. DePorter (2011) identifies the difficulties often faced by adolescents and summarizes them into seven main problems of adolescents, namely: 1) Problematic relationships, 2) Injured feelings, 3) Negative self-image, 4) Fear of big changes, 5) Bad grades in school, 6) Poor focus, and 7) Low motivation.

According to DePorter (2011), the seven problems occur because adolescents and parents often speak through two different perspectives. Parents are fixated on their perspective. Likewise, adolescents speak based on their perspective. One of the causes, Barus (2013) argues that family is no longer seen as an important institution in introducing the views of groups and communities. Family functions are fading and their role has been replaced by internet- based information media.

Through positive interaction and communication within the family, parents and adolescents can strengthen interpersonal relationships (Bailey, 2017), so that adolescents are not easy to believe especially affected by the invitation of friends and exposure to information media. Sacks, et al. (2014) describes that positive relationships with parents, characterized by low conflict, high levels of support, and open communication. For example, frequent parent-adolescent communication and positive identification with parents are associated with less drug abuse, less drinking and smoking among adolescents. Furthermore, adolescents who have good relationship with at least one parent are more likely to have good physical and mental health.

Lickona (2012) asserts that when children do not have a close relationship with their parents and do not know the values that apply in the family, they will become weaker to face pressuresfrom their friends. Thus, harmonious communication between parents and adolescents can lead to good interpersonal relationships, so that good social exchanges occur.

Based on the study above, the author considers it important to study family communication in the midst of the current social change. So far, studies that have focused on the field of communication between adolescents and families have not been widely practiced in Indonesia, especially in the Bogor. Wendari et al., (2016), revealed that $62,44 \%$ of public 
junior high school students in Bogor were in the moderate problem category. Students with moderate problem levels are being interpreted as having behaviors that inhibit, disturb, and hinder themselves from achieving goals and harming themselves and others.

Since 2018 Bogor has been designated as a family friendly city (Saudale, 2018). Research on family communication is very relevant in supporting the vision of Bogor that emphasizes aspects of family resilience. The purposes of this study are: First, to explore the topic of conversation and the interaction of adolescents with families. Second, to describe the four types of communication patterns between adolescents and their families and peers.

\section{Method of Research}

The study was conducted for 6 months (February-July 2014) uses a qualitative approach which is divided into two stages. First, the interview stage through a guided focus group discussion (FGD). This technique was chosen because it allows researchers to control the flow of question and answer (Creswell, 2010). The FGD is intended to explore deeper information. FGD participants were selected purposively from 6 high schools (4 public high schools and 2 private high schools) in Bogor City. Furthermore, 10 students were chosen from each school (5 girls and 5 boys), total participants were 60 people. The number of adolescents is limited so that researchers can explore answers from each participant. FGDs are conducted in each school 2 times, one meeting for teenage girls and another for boys. Thus, the total FGDs for 60 participants are 12 meetings.

When the FGD took place, adolescents were asked to mention their names, ages, and daily activities after school time. Further, the researcher asked a number of questions that had been prepared in the interview guide. One of the questions asked was, "Do you feel more comfortable chatting with parents or friends?" Another question about the daily conversation of adolescents with their parents and peers, such as "What conversation topics are usually discussed with parents? What are you usually talking about with friends?" And "What is your parents' response if you have a different opinion with them?" All answers were recorded by researcher with a tape recorder and handycam with consent of the participants. The researcher also noted important things that happened during the FGD, such as sad or happy expressions when participants gave certain answers.

The second stage, the FGD recordings were transcribed into written form. The next stage is to analyze the results of interviews and map them into four types of adolescent communication, namely (1) Adolescents with high communication patterns with their families and peers, (2) Adolescents with high communication patterns with their families, but have low patterns of communication with their peers, (3) adolescents with low pattern of communication with their families and peers, and (4) adolescents with low patterns of communication with their families, but have high patterns of communication with peers. 
Analysis of interview results follows the steps described by Graneheim \& Lundman (2004). One interview at a time is analyzed by choosing a unit of meaning, which is then condensed and encoded. Further, subcategories, categories and themes were created. Content analysis can filter words into content related to fewer categories. It is assumed that when classified into the same category, words, phrases and the like share the same meaning (Cavanagh, 1997).

\section{Results and Discussion}

The results of this study indicate that adolescents who have a positive relationship with their parents communicate more easily, notify their daily activities, and express their thoughts and feelings. The topic of school is one of the most talked-about by adolescents and parents. Beside that, adolescents and parents oftenly discuss about the choice of future education, political issues, sports, television shows, and hobbies. Some adolescents claim their parents usually ask first about their child's school. Here aresome examples of the expressions.

When I got home, I talked to my mom about school, friends, and exciting events at school (Gi, female, 16 years old).

I told my mom about everything that happens at school,from annoying teachers to extracurricular activities ( $\mathrm{Aj}$, female, 16 years old).

I usually being asked first by my dad, "How's school?" (Ev, female, 16 years old).

I used to talk to my mom and my dad about the future (Ha, male, 16 years old).

My mom usually asks, "Is there any homework for today?" (Sa, male, 18 years old).

I like to talk about political issues with my mother (Ah, male, 16 years old).

However, not all adolescents involved in this FGD have close and positive relationship with their parents. Some adolescents tend to be impassive and keep their distance from parents. They revealed, they were very careful talking about the opposite sex friends. They are worried that parents will get angry, then misperceived when being told about the opposite sex friends. For the sake of avoiding conflict with parents, adolescents choose to share their feelings to their close friends.

I never talk about male friends to parents ( $\mathrm{Ak}$, female, 16 years old).

My mom always says, "Prioritizeyour school and study first", while my dad forbids dating (Ad, female, 16 years old).

My parents said, "No need to date, just get married right away." (Er, male, 18 years old).

On the other hand, some adolescents revealed that their parents did not object to their children dating as long as they did not interfere their learning activities and under supervision of their parents.

My parents don't forbid me from dating as long as I don't neglect my studies and have high marks on my school subjects (An, female, 17 years old).

I was dating and my mom met my girlfriend when I was picked up at school (Ja, male, 16 years old).

My dad allows me to date but I should tell my parents beforehand (In, female, 16 years old).

Most adolescents feel closer to mother than father. A female adolescent (Si, 16 years old), said,

"My dad speaks only if he needs it." He also had no willingness to approach his father because, "I feel disconnected and different in thought with my dad."

Other female adolescent (Mt, 16 year), claimed to be reluctant to talk to her father who worked on the cruise. 
"My father is very busy, so I rarely talk. I once talked about politics with my dad, but I ended up fighting with him. Daddy doesn't want his opinion to be opposed."

It is undeniable that differences in views between adolescents and parents can trigger tension. As revealed by DePorter (2011), adolescents and parents often speak through two different point of views.

Mothers are not only close to their female adolescents, some male adolescents are also claim to be closer to their mothers than their fathers. A male adolescent (Gb, 17 years old), revealed that he had a distance with his father because his father has a very hard character. Similarly, Er (18 years), told that he rarely met his father because of his father's profession as a sailor.

"My communication with Father is only via telephone and social media. I am at home with my mom and brothers. My mom is like an angel to me," Er said, praising her mother.

This finding corroborates the results of research by Silva, et al. (2016), Rudi, et al. (2015), Barbato, et al. (2009), and Heller, et al. (2006) which state that adolescents communicate more often with mothers than fathers. The results of Firdanianty, et al. (2016) study also show similar results that teens are closer, more open, and more often communicate with mothers than fathers. The role of mothers in building family communication can be said to be greater than father. However, some adolescents claim to be closer to father than mother. A female adolescent (Al, 17 years old) revealed,

"I often have disagreement with my mom and when I started to argue with her, I finally chose to be silent. After that, my mother's resentment will subside by itself. I feel closer to my dad."
Another female adolescent, (Lr, 16 years old), conveyed the same thing.

"I often insist on each other with my mom, but eventually my mom tends to give in. If I have disagreement with my mom, I will ask my father's help to mediate. I am closer to my dad than to my mom."

Some adolescents also prefer to talk about the future with their fathers. For example, Pm (female, 17 years old), stated, "It's better to talk about the future with my dad."

In general, adolescents spend more time with their mothers and tend to share feelings with mother. On the contrary, adolescents tend to see fathers as an inappropriate figure to consult with (Steinberg \& Silk, 2002). Both male and female adolescents have the same close relationship with their mothers, but male adolescents tend to bemuch closer to their fathers. This trend will continue to increase throughout adolescence period (Collins \& Laursen, 2004).

Allen and Land (1999) in Collins and Laursen (2004) state that the attachment of parents in adolescence differs from the form of bonding in childhood. Emotional ties to parents are shown in a personal and subtle way, including "teasing" friendships and small actions as a form of attention. In childhood, the sense of security that children receive from their parents will help them explore the environment. Stepping on adolescents, a sense of security will provide the ability and confidence to explore outside family environment, including starting a new relationship with peers or other adults.

Based on the results of interviews that have been analyzed, the author divides the four types of communication patterns 
between adolescents and families and peers as follows.

\section{Type 1. Adolescents with high communica- tion patterns with their families and peers}

Adolescents in this category have closeness and openness to their parents and friends. Their interpersonal skills are good. They volunteered to recount the experiences they met in school either lessons, teachers or friends. The topics discussed were diverse, but for discussion of the opposite sex, adolescents usually express it to parents who have the same sex with them (female adolescents talk to mothers and male adolescents to their fathers).

I talk about everything including my personal problems to my parents ... It's more convenient to tell my mom about male friends ( $\mathrm{Za}$, female, 16 years old).

I talk about everything to my parents. If I need money I will go to my dad, but if you want to go shopping, I always go to my mom (Gl, female, 17 years).

These type of adolescents dare to express their own opinion. This does not mean they have never experienced conflict with parents, but commonly they are not worried because they strongly belief that their parents can accept/understand their opinions. Some adolescents also say that their parents often share life experiences, success stories, advices, and set of good examples at home.

My dad likes to talk about successful people, while my mom shares about feminine issues. My parents also oftenlyask for my opinion (Gl, female, 17 years old).

My dad once said,

"Don't touch women. You may be friends with them as long as you know the limitations "... If I disagree with my parents, we will discuss it and take it as positive and negative sides (Ak, male,
16 years old).

My dad always takes time to pray Maghrib and Isha at home with me and my mom ( $\mathrm{Al}$, male, 16 years old).

If there are any differences of opinion, my parents can accept. Usually we have different opinions when talking about school majors or life point of views (Za, female, 16 years old).

Type 1 adolescents also enjoy hanging out and having lots of friends. They like to chat with friends, both at school and outside of school. Some of them are active in student or extracurricular organizations. In general they have an open personality.

I like to hang out ... (Za, female, 16 years old).

Going home from school my communication with friends continues via telephone, social media, or hanging out in cafes ... (Gl, female, 17 years old).

My close friends are so many, around 25 people. I also have friendsfrom outside of school. I like to chat about anything with friends. In class I am often nosy (Ak, male, 16 years old).

I usually hang out with friends when playing futsal (Al, male, 16 years old).

Type 2. Adolescents with high communication patterns with their families, but have low patterns of communication with their peers.

Adolescents in this category are few in numbers. They feel comfortable and open with their parents, but less close to their friends. They prefer to communicate with parents rather than with friends. This type of adolescents are usually being called "mommy's son or mommy's daughter".

I feel closer to parents than friends (Ha, male, 16 years).

I always ask my mom about women's issues and if I want to discuss political issues with my dad (Ad, female, 16 years old).

I have 5 close friends, and from different classes. I make friends with smarter kids, especially at maths, so that my achievements will be better (Ad, female, 16 years old). 
I am close to friends, but feel closer to parents (Am, female, 16 years old).

\section{Type 3. adolescents with low pattern of com-} munication with their families and peers.

This type of adolescents do not have closeness and are unable to communicate with parents and peers. Their interpersonal skills are not good, so they tend to be impassive and withdraw from relationships. In general they come from families whose parents are very busy and lack of time with their children.

I only have one close friend, since kindergarten. My parents are divorced and I live with my mother. Now my mother has remarried and has a child from the current marriage. There is no time for me (No, male, 16 years old).

I only have one close friend. Almost every day I go home at $9 \mathrm{pm}$. My parents always come home from work late at night. The important thing is, I am already at home when they come from work (In, female, 16 years old).

My parents are very busy with their business, so I rarely talk to them at home. My dadhas to go sailing, sometimes for a year. I don't see my dad so often, when I was little I didn't know that he was my dad. I called him Om (Uncle) (Mu, female, 16 years old).

In general, Type 3 adolescents have a disharmonious relationship with their parents (often disagreements), so they will seek other pleasures. Usually, communication takes place in one direction, from parents to children. Adolescents find it difficult to express their own opinions because their parents tend to avoid listening. Parents often get angry so adolescents feel depressed and choose to close themselves off. For this type of adolescents, teachers become the alternative choices when they need someone to share their feelings.

Sometimes I engage some discussions on political issues with my dad, buteventually, we end up arguing and quarreling. I often feel depressed and difficult to express my own opinion ( $\mathrm{Mu}$, female, 16 years old).

I rarely talk to parents, I prefer playing games. In one day, I can play games for about 4-5 hours, sometimes until $11 \mathrm{pm}$. I play games to kill my time and relieve stress. My parents usually forbid and tell me to stop. I will be angry if they forbid me (Fa, male, 17 years old).

I believe more in teachers than parents or friends (Di, female, 16 years old).

I feel comfortable and fun in talking to my teacher. My parents tend to be demanding and bossy (Mu, female, 16 years).

Type 3 adolescents consider themselves older that their actual age. They don't like gathering and chatting with their friends. Some argue that friends willbring out more negative than positive influences.

I don't like hang out with friends. I have never shared my feelings tomy friends $(\mathrm{Mu}$, female, 16 years old).

I'm not popular at school. If I meet a friend, what I'm talking about is only games (Fa, male, 17 years old).

Friends that I know oftenly give negative influence, such as lazinessand smoking. If I refused, they will say, "You don't have to be preoccupied with your reputation " (Fa, male, 17 years old).

Type 4. adolescents with low patterns of communication with their families, but have high patterns of communication with peers.

This type of adolescentsdo not have closeness to their parents, so they rarely communicate and interact to each other. Like Type 3 adolescents, most Type 4 adolescents come from families whose parents are busy. They are also reluctant to communicate with their parents because they feel uncomfortable, afraid, and do not want to disobey their parents. Some adolescents choose to give in or be quiet rather than having an argument with parents.

I rarely communicate with parents. My mom 
is a lecturer and my father works in Cileungsi. They always come home late at night. If there are personal problems, I often talk to my auntie or my maid (Ni, female, 17 years old).

If I had some disagreements with my parents, I chose to be quiet, listen, and give in (Ni, female, 17 years old).

We never watch TV together because everyone is busy. My opinion sometimes is not being heard ( $\mathrm{Fi}$, female, 17 years).

I rarely confide in my parents because I feel uncomfortable, especially about male friends. I chose to obey what My mom said because I did not want to have disagreements with her (Ak, female, 16 years old).

I just speak only if being asked by my parents. My dad is fierce and assertive. I often give in to my dad's opinion (Ha, male, 17 years old).

The type 4 adolescents' disagreement with their parents makes them tend to be close to their friends. For adolescents of this type, it is more convenient to share their feelings to friends than to parents. The similarities of age, interests, and encountered problems are some of the reasons they are connected to each other. Communication with friends does not only take place in school, but also continues outside of school. Generally, they are being called "Popular Teenagers", because they have so many friends and extensive social networks.

I prefer to trust my friends, because my friends can be more understanding and because we are in the same age (Jo, male, 16 years old).

It's better to tell friends than to parents because I feel much closer to my friends than to my parents (Yes, male, 16 years old).

Best friends are people who can take position for sharing happy and sad stories (Ak, female, 16 years old).

After school, my communication with friends continues via social media. I have 11 close friends. Sometimes we meet at certain place to eat or in my house. Usually we talk about school, boys, parents, and daily activities ( $\mathrm{Ni}$, female, 17 years old).
After school, continue chatting on Line. When you meet outside of school, usually at a place to eat or at home friends (Fi, female, 17 years old).

Usually I have conversations with friends outside of school through social media (Ha, male, 17 years old).

Beside of those four types above, there are also adolescents who are rarely meet their parents because they live in different cities, but they still have closeness to their parents. For example Wil (male, 16 years old), his parents live in Karawang, West Java, while he attends school in Bogor. Even though he meetshis parents once a week, Wil has no communication problems. Every time he returns to Karawang, he will tell his parents about his activities for a whole week and the difficulties he encounters.

"I feel comfortable talking about automotive with my dad and I prefer to talk about lessons, food, or other people, with my mom," Wil said.

Other adolescent who also live far away from their parents is Fa, male, 17 years old. His parents are in Makassar, South Sulawesi. Fa himself chose school in Bogor because,

"... Seeking experience and being successful outside my home town."

Although he lives far from parents, he still communicates via telephone every day and is often video calling via skype. The distance that stretched far does not prevent him from communicating with parents.

The results of typological mapping indicated that communication between adolescents and parents has undergone a shift. Some adolescents claimed to be closer to their friends than parents. There were also adolescents who spent hours playing online games. The findings of Utami, et al. (2015) showed that there was a shift in 
communication culture from face to face communication to computer mediated communication (CMC). According to Barus (2013), family functions have been replaced by information media.

Collins and Laursen (2004) argue that families adapt to individuals and change relationships in diverse ways. Most families build interaction patterns that focus on psychological closeness and reduce the frequency of interactions that used to occur in childhood. They tend to address the needs of adolescents regarding the rights of autonomy and self desires. Families with high internal conflicts and many interpersonal problems are most likely tolack of adaptation patterns needed to form new closeness during the period of the emergence of adolescent withdrawal.

The lack of good communication with parents is one of the problems in the teenage period. Many parents experience conflict with their teenagers. Adolescents consider some parental behaviors as a disruption to their privacy. For most parents and families, this period is a period of tension and rebellion (Valizadeh, et al., 2018).

Two qualities for realizing parentadolescent cooperation are the ability to communicate with adolescents, and the ability to let adolescent seek independence while having strong relationships with parents. Parents who are willing to listen to adolescent have a greater understanding of their children and a high sensitivity to their needs. As a result, adolescents who feel safe are willing to open up and communicate with parents about their anxiety and feelings so that a very positive interaction process was built (Brooks, 2011).

Rudi, et al. (2015) revealed that direct talking is a method of communication that is most often carried out by parents and adolescents, followed by talking on thephone, sending messages, and e-mails. For parents, understanding the communication process in the digital era is important to support the development of adolescents while building positive relationships between family members.

\section{Conclusion}

The positive interaction and communication of parents and adolescents will help create and maintain family ties. Today, many families are busy. Schools, children's activities, and parents' work schedules make family members do not have much time to hang around and do activities together. So far the topic of discussion between adolescents and parents is still dominated by issues that parents need to know and, normally, parents are considered stand on the top structure of the family hierarchy. Parents are bound by their function to prepare their child's future. Not surprisingly, the topic of school and lessons dominates the adolescent-parent discussions.

Likewise, the relationship between adolescents and parents shows the dominance of parents as they feel responsible for their children's future. Some adolescents have dared to express their personal wishes and opinions. On the other hand, some parents are willing to give in and listen to their children's opinions. 
The four typologies of adolescent communication with family and peers are as follows: The first type, adolescents with high communication patterns with their families and peers. The second type, adolescents with high communication patterns with their families, but have low patterns of communication with their peers. The third type, adolescents with low patterns of communication with their families and peers. Finally, the fourth type, adolescents with low communication patterns with their families, but have high patterns of communication with peers.

To prevent adolescents from entering into negative social environments, parents are expected to be able to communicate in a pleasant atmosphere like a friend and consider themselves as good listeners. Parents are suggested to choose topics according to the needs and preferences of adolescents. For example, topics related to the world of adolescence or those that are becoming "hot topic" among adolescents. When children go home from school, parents should start a conversation with questions that are not only answered with the word "yes" or "no", but open questions that must be answered with appropriate and convenientsentences.

\section{References}

Anderson, M., \& Jiang, J. (2018). Teens, Social Media \& Technology 2018. Pew Research Center (US).

Bailey, S. J. (2017). Positive Family Communication. Montana State University (USA): MontGuide.

Ballarotto, G., Volpi, B., Marzilli, E., \& Tambelli, R. (2018). Adolescent internet abuse: a study on the role of attachment to parents and peers in a large community sample. Hindawi Biomed Research International, 1-10. https:// doi.org/10.1155/2018/5769250

Barbato, C. A., Graham, E. E., \& Perse, E. M. (2009). Communicating in the family: an examination of the relationship of family communication climate and interpersonal communication motives. The Journal of Family Communication, 3(3), 123-148.

Barus, M. (2013). Lingkungan keluarga sebagai media komunikasi di era globalisasi. Jurnal Saintech, 5(1), 58-65.

Brooks, J. (2011). The Process of Parenting. Eight Edition. Rachmat Fajar, translator. Yogyakarta (ID): Pustaka Pelajar.

Brown, B.B., \& Larson, J. (2009). Peer Relationships in Adolescence. Handbook of Adolescent Psychology, edited by Richard M. Lerner and Laurence Steinberg. US: John Wiley \& Sons, Inc.

Carr, N. (2011). The Sh@llows. Internet Mendangkalkan Cara Berpikir Kita? Rudi Atmoko, translator. Bandung (ID): Mizan. Translated from: The Sallows: What the Internet is Doing to Our Brains.

Cavanagh, S. (1997). Content analysis: concepts, methods and applications. Nurse Researcher, 4, 5-16.

Collins, W. A., \& Laursen, B. (2004). Parentadolescent relationship and influences. In R. M. Learner \& L. Steinberg, Handbook of adolescent psychology (pp. 331-361). USA: John Wiley \& Sons, Inc.

Creswell, J.W. (2010). Research Design. Pendekatan Kualitatif, Kuantitatif, dan Mixed. Achmad Fawaid, translator. Yogyakarta (ID): Pustaka Pelajar. Translated from: Research Design. Qualitative, Quantitative, and Mixed Methods Approaches. 
DePorter, B. (2011). Mengatasi 7 Masalah Terbesar Remaja. Panduan bagi Orangtua. Edriyani Azwaldi, translator. Bandung (ID): Kaifa. Translated from dari: The 7 Biggest Teen Problems and How to Turn Them into Strengths.

Firdanianty, Lubis, D.P., Puspitawati, H., \& Susanto, D. (2016). Komunikasi remaja dengan ayah masih minim: studi pada siswa sma di kota Bogor. Jurnal Ilmu Keluarga dan Konsumen, 9(2), 124-135.

Friedman T. L. (2009). The World Is Flat. Sejarah Ringkas Abad Ke-21. P. Buntaran et al., translator. Jakarta (ID): Dian Rakyat.

Goldberg, J.S., \& Carlson, M.J. (2014). Parents' Relationship Quality and Children's Behavior in Stable Married and Cohabiting Families. Journal Marriage Family, 76(4): 762-777. doi:10.1111/jomf.12120.

Graneheim, H. U., \& Lundman, B. (2004). Qualitative content analysis in nursing research: Concepts, procedures and measures to achieve trustworthiness. Nurse Education Today, 24, 105-112.

Lickona, T. (2012). Mendidik untuk Membentuk Karakter. Bagaimana Sekolah Dapat Memberikan Pendidikan tentang Sikap Hormat dan Tanggung Jawab. Wamaungo JA, translator. Jakarta (ID): Bumi Aksara. Translated from: Educating for Character: How Our Schools Can Teach Respect and Responsibility.

Morentin, J. I. M., Cortes, A., Medrano, C., \& Apocada, P. (2014). Internet use and parental mediation: A cross-cultural study. Computers \& Education, 70, 212-221. http://dx.doi.org/10.1016/j. compedu.2013.07.036.

Oprea, C., \& Stan, A. (2012). Adolescents' perceptions of online communication.
Procedia, 46, 4089-4091. https://doi: 10.1016/j.sbspro.2012.06.204.

Rudi, J .H., Walkner, A., \& Dworkin, J. (2015). Adolescent-parent communication in a digital world: differences by family communication patterns. Youth \& Society, 47(6), 811-828.

Sacks, V., Moore, K. A., Shaw, A., \& Cooper, P. M. (2014). The family environment and adolescent well-being. Research Brief Child Trends, 52, 1-14.

Saudale, V. (2018). Bima Arya Targetkan Bogor Sebagai Kota Ramah Keluarga. By (www.beritasatu.com/satu/499758/ bima-arya-targetkan-bogor-sebagaikota-ramah-keluarga.htm).

Silva, R. N. A., Bongardt, D. V. D., Jansen, P. V. D. L., Wijtzes, A., \& Raat, H. (2016). Mother and Father-Adolescent Relationships and Early Sexual Intercourse. Pediatrics, 138(6 ), 1-9. https://doi: 10.1542/peds.2016-0782.

Steinberg, L., \& Silk, J. S. (2002). Parenting adolescents. In M. H. Bornstein (Ed.), Handbook of parenting (Vol. 1, pp. 103134). Mahwah, NJ: Erlbaum.

Steinberg, L. (2014). Adolescence. Tenth Edition. USA: McGraw Hill Education.

Suarmini, N.W. (2014). Keluarga sebagai wahana pertama dan utama pendidikan karakter anak. Jurnal Sosial Humaniora, 7(1), 118-135.

Tapscott, D. (2013). Grown Up Digital. Yang Muda yang Mengubah Dunia. Jakarta (ID): Gramedia Pustaka Utama. Translated from: Grown Up Digital. How the Net Generation Is Changing Your World.

Utami, A. M. V., Lestari, M. T., \& Putra, A. (2015). Pergeseran budaya komunikasi pada era media baru. (Studi etnografi virtual penggunaan LINE oleh digital 
natives). e-proceeding Management, 2(3), 4042-4050.

Valizadeh, L., Zamanzadeh, V., Rassouli, M., \& Farshi, M. R. (2018). Concerns of Parents with or Raising Adolescent Children: a Qualitative Study of Iranian
Families. Journal of Caring Sciences, 7 (1), 27-33. https://doi:10.15171/ jcs.2018.005.

Wendari, W. N., Badrujaman, A., Sismiati, A. (2016). Profil permasalahan siswa sekolah menengah pertama (SMP) negeri di Kota Bogor, Insight: Jurnal Bimbingan Konseling, 5(1), 134-139. 